\title{
PEDAGOGIA SURDA E VISUALIDADES: RASTROS CULTURAIS IMAGÉTICOS INDICADORES DE APRENDIZAGEM NA CIBERCULTURA
}

\author{
DEAF PEDAGOGY AND VISUALITIES: IMAGETIC CULTURAL TRACES \\ INDICATORS OF LEARNING IN CYBERCULTURE
}

\section{PEDAGOGÍA Y VISUALIDAD SORDAS: HUELLAS CULTURALES DE IMÁGENES INDICADORES DE APRENDIZAJE EN CIBERCULTURA}

\author{
Rachel Capucho Colacique ${ }^{1}$ \\ Mirian Maia Amaral ${ }^{2}$
}

\begin{abstract}
RESUMO
Este artigo, inspirado numa pesquisa de doutorado que procurou investigar o papel preponderante das visualidades para a aprendizagem das pessoas surdas, em diferentes "espaçostempos" educativos, tem como objetivo central identificas rastros culturais produzidos pelos praticantes surdos, indicadores de aprendizagem, na imbricação cibercultura/cidade. Para isso, buscamos amparo em posicionamentos que norteiam os estudos da visualidade e da pedagogia surda (Ströbel, 2008, 2009); Perlin, 2006; Skliar, 1997), ancorados nos princípios da multirreferencialidade, que exige a adoção de um olhar plural, a partir de sistemas de referências distintos (Ardoino,1998), e nas pesquisas com os cotidianos (Alves, 2012; Certeau, 2013; Andrade, Caldas e Alves, 2019), que enfatizam as práticas pedagógicas, o que possibilitou-nos apreender algumas produções que circulam pela Internet, cujas conversas e narrativas dos praticantes culturais nos forneceram indícios de aprendizagens, que podem auxiliar a prática didática a partir das imagens visuais.
\end{abstract}

Palavras-chave: Cibercultura. Educação de Surdos. Visualidades Indicadores de Aprendizagem.

Submetido em: 15/04/2020 - Aceito em: 25/04/2020 - Publicado em: 29/04/2020

\footnotetext{
${ }^{1}$ Universidade Federal do Estado do Rio de Janeiro - Unirio / Instituto Nacional de Educação de Surdos - INES. Doutorado em Educação pela UERJ. Professora Adjunta UNIRIO e professora EBTT/INES.

${ }^{2}$ Fundação Getúlio Vargas
} 


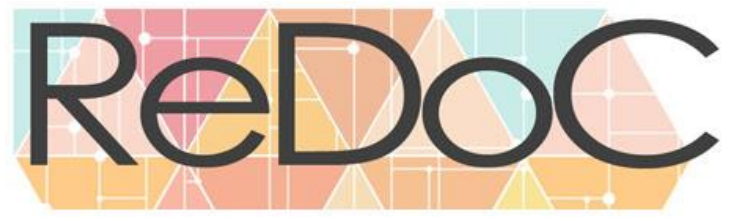

Revista Docência e Cibercultura

\begin{abstract}
This article, inspired by a doctoral research that sought to investigate the preponderant role of visualities for the learning of deaf people, in different educational "time spaces", has as the main objective of identify cultural traces produced by deaf practitioners, learning indicators, in the interrelation of cyberculture and city. For this, we seek support in positions that guide the studies of visuality and deaf pedagogy (Ströbel, 2008, 2009); Perlin, 2006; Skliar, 1997), anchored in the principles of multi-referentiality, which requires the adoption of a plural view, based on different reference systems (Ardoino, 1998), and in research with everyday life (Alves, 2012; Certeau, 2013; Andrade, Calas e Alves, 2019), which emphasize pedagogical practices, which which enabled us to allowed us to us to apprehend some productions that circulate on the Internet, whose conversations and narratives of cultural practitioners provided us with evidence of learning, which can help the didactic practice from visual images
\end{abstract}

Keywords: Cyberculture. Deaf Education. Visualities. Learning Indicators

\title{
RESUMEN
}

El presente texto, inspirado en una investigación doctoral que buscó investigar el papel preponderante de las visualidades para el aprendizaje de las personas sordas, en diferentes espacios e tempos educativos, tiene como objetivo central identificar pistas culturales producidas por practicantes sordos, indicadores de aprendizaje, en la interrelación de la cibercultura y ciudad. Para esto, buscamos apoyo en posiciones que guíen los estudios de visualidad y pedagogía sorda (Ströbel, 2008, 2009; Perlin, 2006; Skliar, 1997), ancladas en los principios de multirreferencialidad, que requiere la adopción de una mirada plural, basada en diferentes sistemas de referencia (Ardoino, 1998), y en la investigación con la vida cotidiana (Alves, 2012; Certeau, 2013; Andrade, Caldas e Alves, 2019), que enfatiza las prácticas pedagógicas, lo que nos permitió aprehender algunas producciones que circulan en Internet, cuyas conversaciones y narraciones de practicantes culturales nos proporcionaron evidencia de aprendizaje, que puede ayudar a la práctica didáctica a partir de imágenes visuales.

Palabras clave: Cibercultura. Visualidades Educación para sordos. Indicadores de aprendizaje

\section{Introdução}

Muitas políticas têm sido implementadas pelos Governos, na expectativa de reduzir o distanciamento entre os surdos e a comunidade ouvinte e, dessa forma, contribuir, para a inclusão educativa dos surdos. Um exemplo disso é a Lei no 7.853/89 (BRASIL, 1989) que, em seu art. $1^{\circ}$ assegura a interação social das pessoas com deficiência, tendo as escolas regulares como espaços relevantes desse processo.

No entanto, em termos práticos, essa lei tem sido objeto de muitas discussões no meio acadêmico. Ainda que, nos últimos anos, tenha havido um crescimento considerável de matrículas de alunos com deficiência na rede pública, respaldadas por essa Lei que lhes 


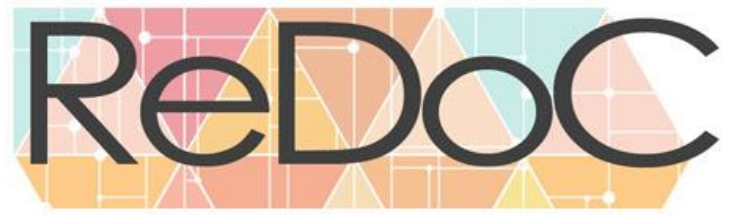

\section{Revista Docência e Cibercultura}

garante o direito de frequentar as salas de aulas de escolas regulares e, quando necessário, receber tratamento especializado fora dos horários de aula, ainda existem muitos desafios a serem enfrentados, para que os objetivos dessa inclusão se efetivem. Entre eles, podemos citar a formação de professores para lidar com esses estudantes, o aprimoramento das práticas pedagógicas, a melhoria da infraestrutura escolar (acessibilidade arquitetônica e tecnológica), a criação de redes de aprendizagem e o estabelecimento de parcerias junto a entidades públicas especiais como, por exemplo, o Instituto Nacional de Educação de Surdos - INES.

Lacerda (2006) aponta que com as políticas de inclusão ganhando força no mundo todo, no final da década de 1990, os programas de educação especial sofreram grande desprestígio, e o incentivo maciço para as práticas de inclusão de pessoas surdas em escolas regulares de ouvintes mostraram que os diferentes modelos de inclusão implementados acabaram gerando, em muitos casos, uma "escolarização pouco responsável”. A escola até recebe bem a criança, inicialmente, mostrando-se aberta à ideia de inclusão, mas o dia a dia revela poucas ações efetivas no sentido de atender a essas necessidades. Para a autora, as fragilidades das propostas de inclusão residem, frequentemente, no discurso que contradiz a realidade prática do sistema educacional brasileiro, já com tantos sinais de precariedade.

As pesquisas desenvolvidas no Brasil e no exterior indicam um número significativo de estudantes surdos que, mesmo passando por vários anos de escolarização, ainda apresentam competências acadêmicas abaixo do desempenho de estudantes ouvintes, o que evidencia uma inadequação do sistema de ensino. Para a autora, esses dados indicam a urgência de medidas que favoreçam o desenvolvimento pleno desses sujeitos.

O modelo inclusivo sustenta-se em uma filosofia que advoga a solidariedade e o respeito mútuo às diferenças individuais, cujo ponto central está na relevância da sociedade aprender a conviver com as diferenças. Contudo, muitos problemas são enfrentados na implementação desta proposta, já que a criança com necessidades especiais é diferente, e o atendimento às suas características particulares implica formação, cuidados individualizados e revisões curriculares que não ocorrem apenas pelo empenho do professor, mas que dependem de um trabalho de discussão e formação que envolve custos e que tem sido muito pouco realizado. A inclusão apresenta-se como uma proposta adequada para a comunidade escolar, que se mostra disposta ao contato com as diferenças, porém não necessariamente satisfatória para aqueles que, tendo necessidades especiais, necessitam de uma série 


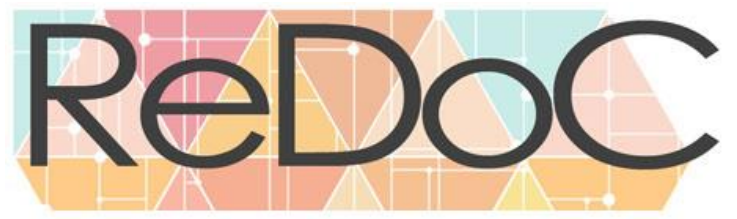

\section{Revista Docência e Cibercultura}

de condições que, na maioria dos casos, não têm sido propiciadas pela escola (LACERDA, 2006, p. 166).

Em princípio, como base fundamental do direito inerente aos indivíduos, a educação deve mesmo ser considerada um bem inclusivo, de todos, para todos. Mas, em se tratando de prática pedagógica cotidiana, ali no fazer diário do planejamento das aulas, da execução, das tarefas propostas, ela não pode ser imposta como uma fôrma pré-moldada, sob pena de excluir, justamente quem se pretende agregar.

Ao se referir às questões relacionadas à igualdade e diferença, Santos, B. e Nunes (2003, p. 56) afirma:

Temos o direito de ser iguais quando a nossa diferença nos inferioriza; e temos o direito de ser diferentes quando a nossa igualdade nos descaracteriza. Daí a necessidade de uma igualdade que reconheça as diferenças e de uma diferença que não produza, alimente ou reproduza as desigualdades.

Pensar a inclusão do estudante surdo é, portanto, pensar uma inclusão que reconheça suas diferenças, sem reproduzir as desigualdades as quais já foram expostos por anos de escolarização não responsável. A valorização e garantia das condições linguísticas e culturais das crianças surdas são fundamentais. Mas é importante lembrar que não basta a presença do intérprete apenas (LACERDA, 2006, p. 176), são necessárias uma série de outras providências para que o aluno seja atendido de maneira efetiva - adequação curricular, aspectos didáticos e metodológicos, conhecimentos sobre a surdez e sobre a língua de sinais, entre outros - para que o aluno possa desenvolver-se em todo seu potencial cognitivo e humano.

É importante destacar também que uma parte significativa da comunidade surda não é a favor das salas de aula inclusivas, pelo menos não do modo como vem sendo aplicada em muitos lugares. Eles defendem o ensino bilíngue, preferencialmente com turmas exclusivas e professores surdos, de modo a garantir a vivência cultural surda, de forma plena.

Com a criação da Lei 10.436/2002 (BRASIL, 2002) que, regulamentada pelo Decreto 5.626/2005 (BRASIL, 2005), reconhece a Língua Brasileira de Sinais (LIBRAS) como língua oficial das comunidades de surdos, o espaço escolar passa a utilizar intérpretes, facilitando, 
desse modo, a interação entre surdos e ouvintes. Na tentativa de explicar como se efetua essa interação, Amaral, L. (1998) se apropria da metáfora da ponte movediça em sua relação com o castelo. A ponte movediça (os ouvintes) permite o trânsito entre a cidade e o castelo (surdos). Em outras palavras, os ouvintes utilizam a ponte movediça para chegar até os surdos. A ponte liga, portanto, os ouvintes aos surdos, promovendo a interação entre eles. No entanto, acentua a autora, a travessia dessa ponte consiste numa escolha; ou seja, quebrar barreiras, pois a possibilidade do encontro depende do interesse de cada pessoa.

A inclusão dos surdos no mercado de trabalho, por intermédio da Lei no 8.213/91 (BRASIL, 1991), também tem sido considerada positiva, na medida em que garante um percentual de vagas para pessoas com deficiência, nas empresas que possuem acima de 100 funcionários. No entanto, a inclusão dessas pessoas nas empresas altera suas rotinas, na medida em que devem oferecer um curso de capacitação de LIBRAS para os funcionários, com vistas à interação com os surdos, dado que essa interação não acontece somente no campo linguístico, mas, também, em termos de valorização e respeito à cultura surda.

Outro fator de inclusão que vem sendo apontado, positivamente, pela comunidade surda é a inserção da tradução em LIBRAS em eventos culturais, artísticos e programas de televisão. Propagandas políticas e canais públicos - como a TV Senado, por exemplo - também vêm garantindo a janela com o intérprete em rede nacional. Recentemente, a equipe de intérpretes que fez a tradução da sessão do Supremo Tribunal Federal (STF) que julgou o habeas corpus do ex-presidente Luiz Inácio Lula da Silva, foi destaque nos dias que seguiram. Trabalhando incessantemente por mais de 12 horas - tempo que durou o julgamento - os intérpretes foram chamados de 'corajosos' e chegaram a virar memes ${ }^{3}$ na Internet. Segundo eles, a aceitação pela comunidade surda da tradução, nas sessões do STF, tem sido extremamente boa, pois eles, finalmente, podem acompanhar o que acontece no Judiciário.

\footnotetext{
${ }^{3}$ Consiste numa ideia, conceito, sons ou qualquer outra informação que viralize, sendo copiada ou imitada na rede. Mais detalhes disponíveis em: http://emais.estadao.com.br/noticias/comportamento,interprete-deLIBRAS-no-julgamento-de-lula-diz-que-ficou-assustada-com-repercussao-na-internet,70002262429. Acesso em: 03 abr. 2019.
} 
Essas possibilidades de inclusão nas diferentes esferas sociais são fundamentais para se pensar - e repensar - a inclusão escolar dos surdos, uma vez que não basta estar presente em sala de aula, mas é preciso ter garantidas as condições para o aprendizado de fato, sempre prezando pela valorização da cultura surda, e garantindo o pleno acesso à Língua Brasileira de Sinais.

Problematizar aqui a questão da inclusão não é tentar demonizar a proposta, ou contrariá-la, a todo custo, mas buscar apontamentos para uma educação de qualidade. Questionar esses processos de inclusão é um dever, uma questão de humanidade, de direitos, de dignidade.

Lacerda (2006) nos fala ainda sobre uma inclusão cuidadosa - que se opõe à inclusão pouco responsável - em que o surdo não esteja apenas fisicamente presente, mas que seja considerado em todos os seus aspectos; que possibilite não apenas contato com grupos de ouvintes e surdos, mas que efetivamente beneficie os dois grupos. Sobre isso, a autora ainda aponta a criação de uma 'falsa imagem de sucesso', já que, se o estudante não apresentar muitos problemas para a escola - de comportamento, notas, disciplina - ela tende a se acomodar a um tratamento dado, de forma limitada e superficial.

As conclusões do estudo apontam, portanto, que a "inclusão no ensino fundamental é muito restritiva para o aluno surdo, oferecendo oportunidades reduzidas de desenvolvimento de uma série de aspectos fundamentais (linguísticos, sociais, afetivos, de identidade, entre outros)" (p. 176), e enfatiza que a simples 'adaptação' ao ambiente não pressupõe garantia de educação de qualidade. O aluno não 'perturba' a escola, mas isso não significa que esteja sendo parte ali de fato.

Essa falsa inclusão é preocupante. Ströbel (2008) nos alerta sobre um jogo de camuflagem, ou de máscaras, envolvendo a relação entre surdos e ouvintes. Para a autora, os neo-ouvintistas aqueles indivíduos que, querendo impor o modelo ouvinte de ser e estar no mundo - usam máscaras de aceitação cultural de surdos, citando, como exemplo, os corais de surdos que mais parecem marionetes, e nem ao menos participam da escolha e tradução das músicas, repetindo tudo o que é sinalizado pelo regente apenas para fazer algo que agrada a comunidade ouvinte. 
Essas práticas veladas, mascaradas de benevolência ou aceitação, estão presentes em muitas relações estabelecidas nas diferentes esferas da vida cotidiana. Isso exige refletir sobre nossas próprias práticas e motivações. A forma de contribuirmos om a comunidade surda, é na participação conjunta, é no cotidiano do fazer com e não fazer para.

Santos, S. (2013), em sua dissertação de mestrado em Educação Ambiental da Universidade Federal de Rio Grande (FURG), procurou investigar os potenciais dos recursos imagéticos na educação ambiental de sujeitos surdos, como propulsores de processos interativos, utilizando algumas obras de arte como disparadoras dos conteúdos. Entre os resultados alcançados, ela observou que os recursos imagéticos permitiram maior liberdade aos estudantes, que falaram de suas vidas, medos e aspirações, lembrando coisas que talvez nem se lembrassem sem o apoio da imagem, refletindo sobre temáticas sobre as quais não haviam pensado antes, como pode ser evidenciado na fala da estudante surda $\mathrm{Maria}^{4}$, que confirma o êxito do uso desses recursos no processo de significação dessas imagens.

Praticante Maria: Eu fiquei impressionada como a gente pode encontrar imagens que nos identificam, saber que elas podem fazer pensar sobre o que passamos, entender as nossas motivações e desejos, acho que é muito importante usar esse tipo de recurso pra saber o que o surdo realmente tem no coração. $\mathbf{O}$ visual, isso atinge o coração do surdo! Parece que a imagem já responde pelo surdo, ela é um meio muito importante! Até porque cada imagem parece que tem um sentido escondido, cada um vê de uma maneira e isso ajuda a saber um pouco sobre a história de vida daquele surdo, o jeito que ele vê o mundo.

Com efeito, a temática da imagem é pulsante. No campo das representações visuais desenhos, pinturas, fotografias, entre outros - ou no campo imaterial das representações mentais - fantasia, imaginação, esquemas e modelos em geral, o poder arraigado dos signos e representações funda e fundamenta nossos pensamentos, ações e expressões.

Nesse universo imagético, a temática da aprendizagem visual nos interessa a todos. Na medida em que, como pesquisadores, somos parte dessa hiper-realidade visual, precisamos estar atentos não apenas aos conteúdos produzidos e veiculados nas redes, mas, também, ao

\footnotetext{
${ }^{4}$ A autora do texto original utilizou nome fictício, pois não obteve autorização para atribuir à praticante, seu nome verdadeiro.
} 


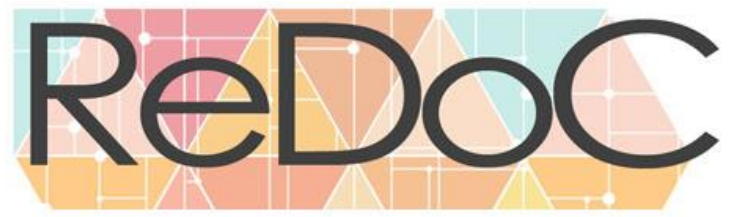

Revista Docência e Cibercultura

modo como eles se evidenciam, analisando-os, desconstruindo-os e os reconstruindo, para melhor compreendermos o que está sendo proposto e os sentidos que expressam.

Desse modo, este artigo, fundamentado numa pesquisa de doutorado que investigou o papel das visualidades para a aprendizagem das pessoas surdas, em diferentes "espaçostempos" de aprendizagem, tem como objetivo identificas rastros culturais imagéticos produzidos pelos praticantes surdos, no inter-relacionamento cibercultura/cidade.

\section{Visualidades e caminhos surdos de apreensão do mundo}

A experiência visual, para o surdo, é algo tão gigantesco, que chega a ser difícil pôr em palavras. Inúmeros relatos apresentam um pouco dessa dimensão imensurável que é a importância da visualidade na constituição dos sujeitos, nas subjetividades, na identidade das pessoas surdas, e nos processos de compreensão e apreensão de mundo.

Campello (2008) enfatiza o impacto que a experiência visual-linguística exerce na constituição do sujeito surdo. Enquanto surda, a autora nos lembra de que a própria língua de sinais já carrega em si características que vão originar processos de comunicação constituídos por imagens. Afirma, ainda, que os canais sensoriais que ligam - e mediam - os seres humanos com o meio, possibilitando as representações simbólicas de mundo, são propiciadores das condições fundantes dos sujeitos. Ou seja, na ausência dos canais sensoriais da audição, os sujeitos desenvolverão mediações diferentes; o que, no caso dos surdos, é substituído e potencializado pela visão.

A experiência da visualidade produz subjetividades marcadas pela presença da imagem e pelos discursos viso-espaciais provocando novas formas de ação do nosso aparato sensorial, uma vez que a imagem não é mais somente uma forma de ilustrar um discurso oral [...] Os sujeitos surdos constituem-se como sujeitos mediados por referências diferentes das dos não surdos. Vão aos poucos tomando ciência de que o "seu mundo" é um mundo sem som e não se sentem incomodados por não ouvirem [...] a ausência [de som] é substituída pela visão, que é condicionada de acordo com a percepção visual que vai sendo construída no e do mundo (p. 22; 86). 
Nessa mesma linha, Marques (1999), afirma que os signos visuais vão compor não só o cotidiano dos sujeitos, mas toda a gama de subjetividades, e suas bases cognitivas. Assim, a visualidade contribui para a o aprimoramento de esquemas de pensamento, por meio da criação de conceitos visuais, denominado pensamento plástico:

[...] Um pensamento que decorre de um conhecimento fundamental, que atravessa ideias e comportamentos através de uma linguagem. Tal linguagem existe através de imagens e representações mentais que informam a percepção da realidade de acordo com características intelectivas próprias (p. 1).

Os processos visuais de percepção de mundo originarão mecanismos mentais distintos daqueles apresentados pelas pessoas ouvintes, uma vez que as estratégias intelectivas e os esquemas de pensamento estarão atrelados, inerentemente, aos modos visuais de operação cognitiva dos surdos. Esses processos visuais estruturarão as representações mentais, conferindo à percepção da realidade características intelectivas próprias. Ao enfatizar a importância que tem esse tipo de pensamento, na formação das bases cognitivas das pessoas surdas, a autora nos fala:

Assim, o pensamento da pessoa surda é dependente das imagens não só para expressar, mas para existir. Cada imagem relaciona alguma coisa com outra, estabelecendo sucessivas relações. Cada imagem se movimenta, amadurece e se desenvolve, desempenha uma função, soluciona um problema. Este fluxo de imagens acontece como tipo de linguagem-vida interior. [...] A imagem é, portanto, a linguagem fundamental para o surdo, a forma e o meio mais completo de verificação perceptiva e de representação, desempenhando a função essencial na reflexão e na elaboração de estratégias de pensamento e ação (Idem, p. 1).

Compreender a importância que a visualidade assume na constituição dos surdos, e suas bases cognitivas, é fundamental para se pensar e discutir os processos de aprendizagem desses sujeitos. A sinalização, em LIBRAS, constitui um dos elementos fundamentais para a aprendizagem dos surdos; mas, pensar visualmente engloba muitas outras competências. Nessa perspectiva, Como guiar os professores em uma mudança de planejamento escolar diante de uma pandemia?os por 'Pedagogia da Diferença', pela pesquisadora surda Gládis Perlin, em 2002, leva em conta as diferenças linguísticas, cognitivas e culturais dos sujeitos surdos, na prática pedagógica. 


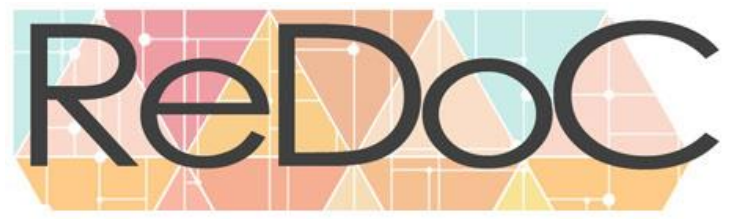

\section{Revista Docência e Cibercultura}

Ströbel (2009), assim como as diferentes identidades surdas, movimentos surdos, comunidades surdas, fontes históricas, memórias surdas e outros artefatos culturais, coloca a pedagogia surda como característica cultural da comunidade, devendo legitimar o modelo cultural do 'Ser Surdo'. Para a autora, as crianças surdas se beneficiam do contato cotidiano com surdos adultos, fortalecendo suas subjetividades e aprendendo melhor. Assim, é imprescindível que os professores estejam atentos à transformação requerida em suas práticas, elaborando estratégias didáticas que respeitem e valorizem os artefatos culturais dos próprios alunos.

Além da valorização da diferença, a pedagogia surda se caracteriza pela presença do professor surdo na instituição - que oferecerá aulas ministradas em LIBRAS desde a educação infantil para as crianças surdas, por meio da mediação cultural, enfatizam Streiechen et al. (2017). Para os autores, as práticas educativas serão mais efetivas se houver um professor bilíngue ouvinte, juntamente com o profissional surdo atuando em sala de aula. Acreditam que a construção da subjetividade cultural é o ponto primordial dessa proposta formativa, primando pela "diferença como construção sociológica na defesa de uma liberdade social onde o sujeito surdo está presente" (p. 99). Desse modo, a pedagogia surda surge com a finalidade de atender às especificidades do sujeito surdo, de modo a considerar a riqueza de seus aspectos culturais do 'jeito de ser surdo', fortalecendo identidades.

Por sua vez, Vilhalva (2004, p. 3), ressalta que a Pedagogia Surda considera o desenvolvimento natural do educando, bem como a construção e valorização da identidade surda, por meio da língua de sinais, sem interferência da oralidade. Para ela, a Pedagogia Surda envolve:

um sistema educativo próprio, abrangendo sem limite de lugar, podendo ser contempladas através das histórias em LIBRAS e passadas pelos Surdos sinalizadores mais velhos [...] Os sinais, as histórias, os hábitos que fazem a formação v suo-espacial, tudo que pertence a Cultura Surda transmitida pela Língua de Sinais.

No entanto, Ströbel (2008) e Perlin e Ströbel (2008) utilizam o termo 'Pedagogia da Diferença' - linha de pensamento do campo educacional que visa à inclusão de grupos 
tradicionalmente minoritários e/ou marginalizados e o respeito para com a diversidade existente nas classes escolares - já englobando as propostas aqui mencionadas.

A pedagogia surda consiste em fundamentar a educação de surdos em traços da diferença e mediação cultural, asseveram Perlin e Ströbel (2008, p. 19).

\begin{abstract}
Fundamentar a educação de surdos nesta teorização cultural contemporânea sobre a identidade e a diferença parece ser o caminho hoje. [...] A modalidade da 'diferença' se fundamenta na subjetivação cultural. Ele surge no momento que os surdos atingem sua identidade, através da diferença cultural, surge no espaço pós-colonial. Neste espaço não mais há a sujeição ao que é do ouvinte, não ocorre mais a hibridação, ocorre a aprendizagem nativa própria do surdo
\end{abstract}

Perlim (2006) também utiliza o termo 'Pedagogia da diferença surda', sublinhando que essa proposta seria uma tentativa de emancipação cultural pedagógica, capaz de romper com séculos de negação de subjetividade e tentativa de normalização da deficiência, a qual o sujeito surdo esteve submetido.

A adoção de uma pedagogia que considere as diferenças e leve em conta a realidade brasileira de diversidade e pluralismo, faz-se, portanto, necessária, dado que vivemos num mundo complexo e em constante transformação, mas que vem sendo construído a partir de lógicas e saberes legítimos pautados num discurso hegemônico que nos faz ver primitivismos, particularidades, inferioridades, ignorância e improdutividade. Nesse contexto, corroboramos o pensamento de Campello (2008), compreendendo a Pedagogia Surda como aquela pautada nos princípios já expostos, fundamentalmente no que diz respeito à visualidade.

Por isso, utilizaremos, neste artigo, a expressão Pedagogia Surda, no sentido de uma 'Pedagogia das Visualidades'; que contemple os seguintes aspectos levantados por aquela autora:

- $\quad$ Formar professores - toda e qualquer proposta educativa deve estar pautada na compreensão e valorização da cultura, identidade, história dos movimentos sociais, educacionais e políticos dos surdos, bem como na gramática da língua de sinais, e aspectos do ensino de língua portuguesa como segunda língua;

- habilitar o estudante ao exercício visual - compreendendo a importância da visualidade, o professor deve exercitar modos de captação e transmissão dos signos visuais 
durante suas aulas, atrelando suas práticas às perspectivas visuais e culturais dos estudantes surdos;

- $\quad$ entranhar os artefatos culturais da diferença surda - fundamentados em uma visão crítica e, conscientes das diferenças da cultura linguística distinta, os professores devem refletir sobre os mesmos e incorporar, em suas práticas, os aspectos pertinentes a essa cultura;

- $\quad$ objetar, de forma consciente, a 'resistência' dos 'discursos' dos profissionais surdos - valorizando a presença do professor surdo nos espaços educativos; e

- $\quad$ alternar as formações e currículos das faculdades - promovendo a inserção de disciplinas de educação de surdos nos currículos educacionais como um todo.

Muitos são os exemplos de práticas educativas alicerçadas nessas premissas. Jorge (2013), em sua dissertação sobre os processos avaliativos no ensino de espanhol para estudantes surdos, relata que, de uma forma geral, percebeu, na rotina da sala de aula, que os alunos surdos, mesmo que inconscientemente, sinalizavam o desejo por atividades mais apropriadas a sua realidade, dando destaque ao comentário de Laura, que, em entrevista realizada pelo autor, no dia 06/09/2012, comemorou o fato de a professora propor uma atividade avaliativa diferenciada sob a forma de um ditado. Enquanto os alunos ouvintes realizavam um ditado oral em espanhol, sobre cores, os alunos surdos realizavam uma atividade escrita com o mesmo conteúdo. No entanto, essa atividade trazia as proposições em LIBRAS e em português.

Laura (interpretada por Alice ): - Quinta-feira teve prova.

Maria (professora): - Foi o ditado. Foi feito ditado.

Eliane (pesquisadora): - O que houve?

Laura (interpretada por Alice): - Foi bom o ditado! Gostei de fazer o ditado! Foi fácil! Porque tinha desenho, tinha LIBRAS. Então ficou mais fácil responder em Espanhol.

Os desenhos mencionados pela aluna são trazidos naquela dissertação, como mostra a Figura 1 , a seguir.

Figura 1- Comentários sobre a avaliação 
Revista Docência e Cibercultura

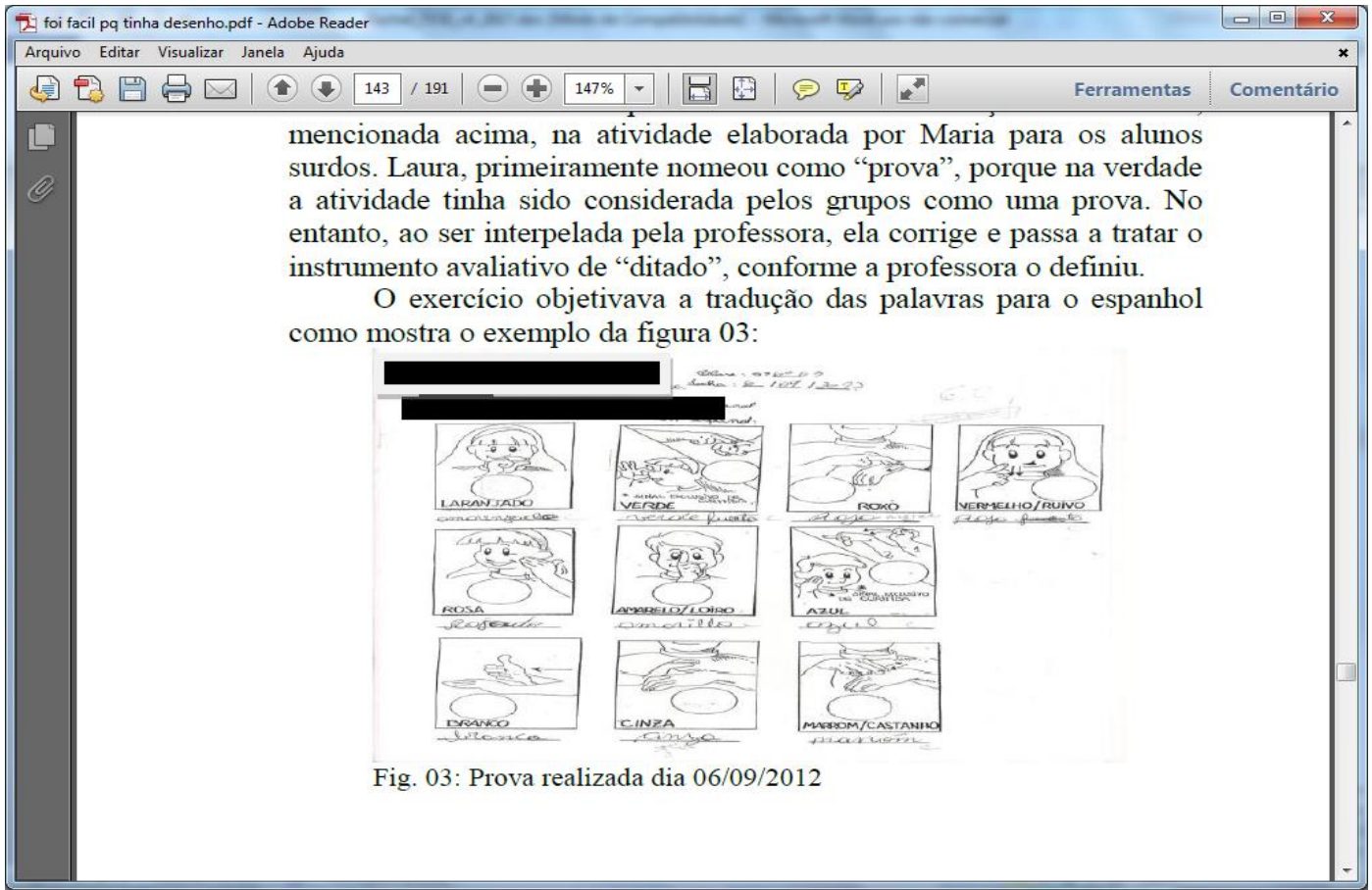

Fonte - Jorge, 2013, p. 143.

Silva e Kanashiro (2015) também trazem dados relevantes sobre a importância da avaliação visual para estudantes surdos, concluindo que as avaliações escritas em língua portuguesa acabavam gerando uma grande ansiedade nos estudantes - por não terem pleno domínio da língua escrita, com resultados insuficientes e frustrantes, para alunos e professores.

Foi observado que os parâmetros usados para avaliar os alunos ouvintes não atingiam da mesma maneira os alunos surdos. O ouvinte, em dia de avaliação, recebia a prova escrita sem fotos ou qualquer referência a um texto não verbal. Fazia a leitura silenciosa de forma autônoma e, a partir de suas inferências, começava a expor seus pensamentos na forma de escrita da língua portuguesa. Dos alunos surdos, três possuíam uma base do português, mas não dominavam todas as técnicas de letramento. Ao tentarem reconhecer os gêneros textuais, ficavam confusos, pois a LIBRAS, língua natural deles, e a língua portuguesa não são semelhantes em alguns aspectos, como os conectivos: preposições, adjuntos, artigos (p. 699).

Em face dessa realidade, foi criada uma plataforma de avaliação para aplicação de provas diferenciadas, que possibilitou independência e autonomia na resolução das questões, uma 


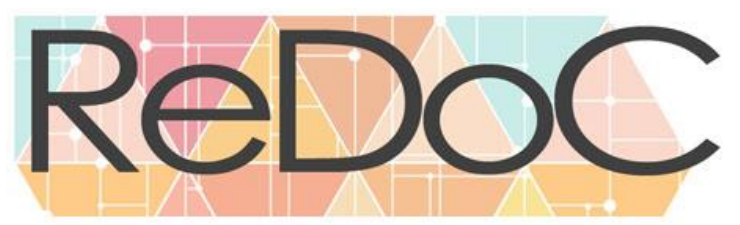

\section{Revista Docência e Cibercultura}

vez que o material oferecia tanto os sinais em LIBRAS, quantos outros correspondentes imagéticos relacionados aos conteúdos, como mostra a Figura 2.

Figura 2 - Plataforma criada para aplicação de provas diferenciadas

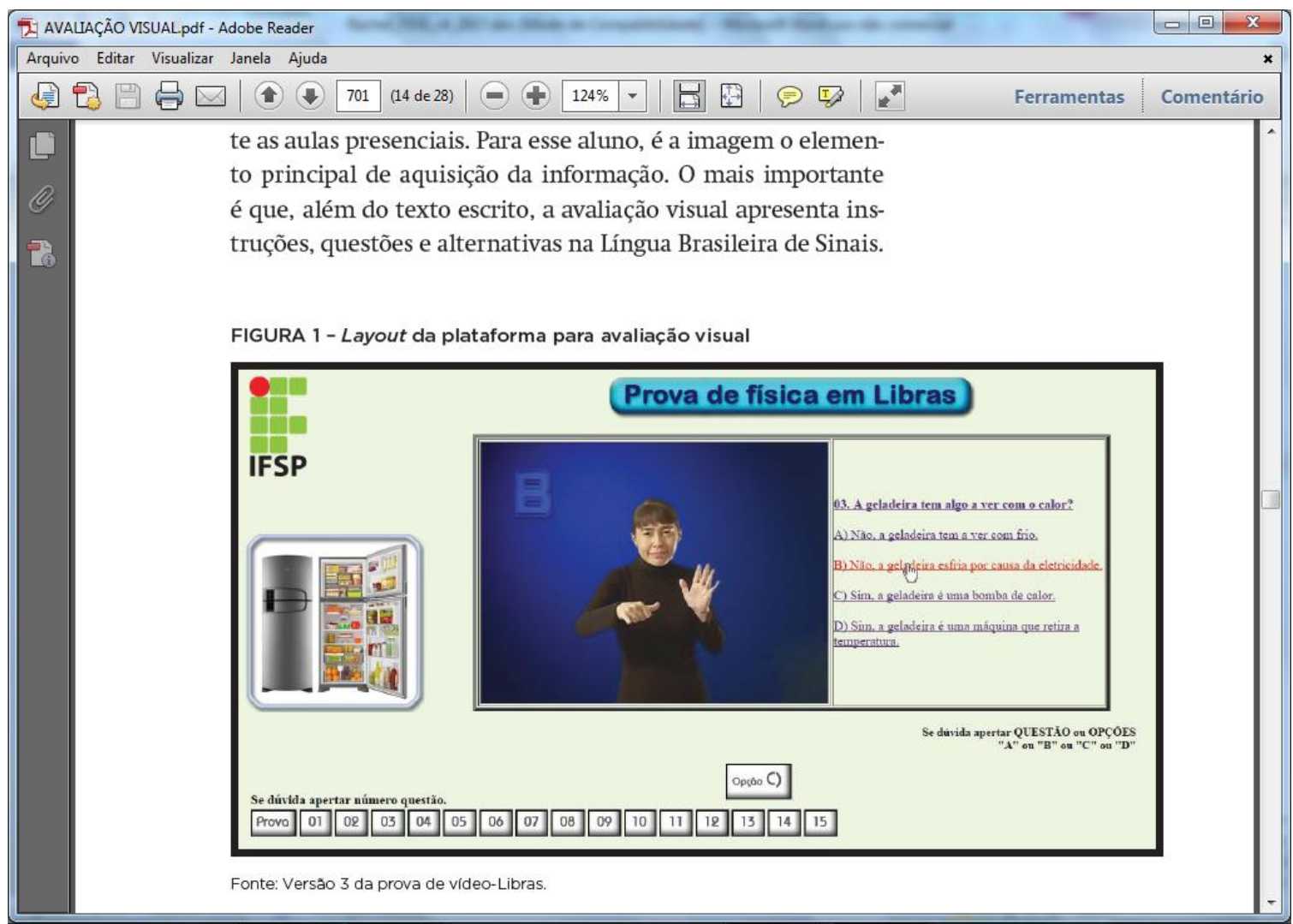

Fonte - Silva e Kanashiro, 2015, p. 701.

"O mais importante é que, além do texto escrito, a avaliação visual apresenta instruções, questões e alternativas na Língua Brasileira de Sinais” (p. 701), asseveram os autores.

Importante destacar que não se trata apenas de incluir alguma ilustração no texto, mas imagens que produzam sentidos e gerem compreensão. Muitos materiais trazem imagens, mas às vezes são mais ilustrativas do que elucidativas, ou complementares. Servem, dessa forma, ao propósito estético do texto didático, mas pouco acrescentam ao processo de aquisição e compreensão do conhecimento ali representado. "Ficar olhando somente fotos nas apostilas 
não ajuda a contextualizar; por isso eles ficavam nos 'achismos' de sempre” (p. 702). Adicionalmente, foi feito todo um trabalho de ampliação e apropriação de vocabulário com esses alunos, com sinais específicos da área estudada. Com essas ações conjuntas, foi possível observar, nos estudantes, maior envolvimento, motivação e autonomia, uma vez que poderiam sair da tutela do intérprete para realizar as provas, com melhorias nos resultados de suas avaliações.

Com a avaliação visual, eles entenderam as questões - entenderam o que se perguntava e o que se queria que eles fizessem. Não perderam partes da interpretação por conta da maior ou menor agilidade desse ou daquele aluno e puderam apreciar todas as descrições. Em virtude disso, a avaliação visual permitiu uma apreensão em primeira ordem, uma interpretação preparada anteriormente e que cada um poderia ver e rever, da mesma forma, quantas vezes fossem necessárias - assim como faz um aluno ouvinte ao ler e reler as questões. A avaliação visual, realizada como prova de múltiplas escolhas, foi percebida como um elemento positivo. Ao integrar diversos elementos, como figuras, textos e interpretação em LIBRAS, além de facilitar o entendimento do aluno, evitou também que sua dificuldade de expressão na língua escrita prejudicasse a qualidade das respostas que cada um poderia oferecer. Eles relataram que as questões não eram difíceis, embora não soubessem as respostas. Conseguiram perceber que precisavam estudar mais e apontaram que a apostila não os ajudava (SILVA; KANASHIRO, 2015, p. 708).

Em nossas práticas cotidianas se torna fundamental a criação de materiais que possam contribuir com os processos de aprendizagem visual. Nessa perspectiva, podemos utilizar, por exemplo, fotos da turma em suas atividades, fotos de família, perfis e postagens retirados da Internet, seleção de jornais, matérias de revista, histórias em quadrinho, cartas, bilhetes, convites, receitas, confecção de maquetes, entre inúmeras outras possibilidades surgidas ao longo do ano escolar. Um exemplo simples de atividade aplicada para aprofundar vocabulário de Língua Portuguesa, com o uso de imagens, é destacado, a seguir, na Figura 3. 


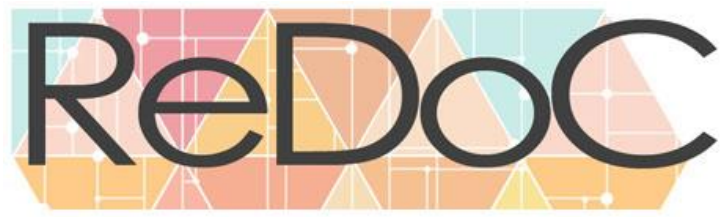

Revista Docência e Cibercultura

Figura 3 - Atividade apoiada no uso de imagens

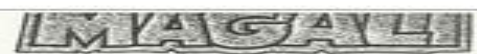
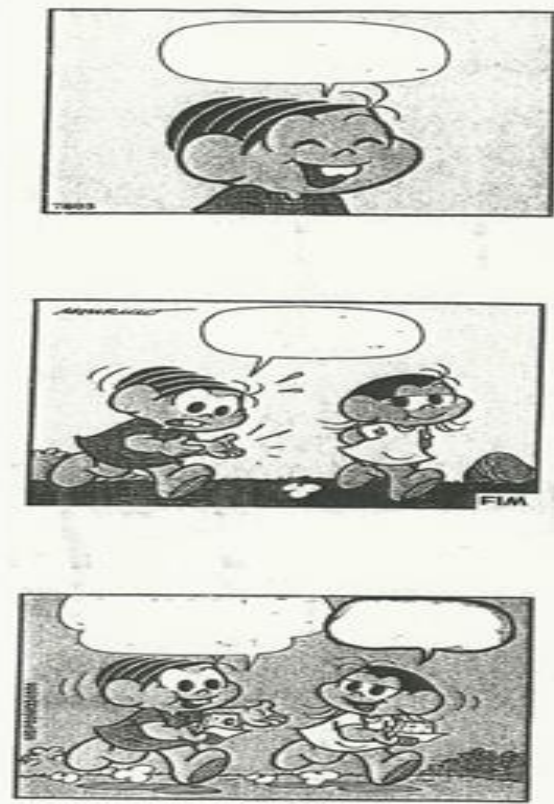

\section{Hnioringe:}
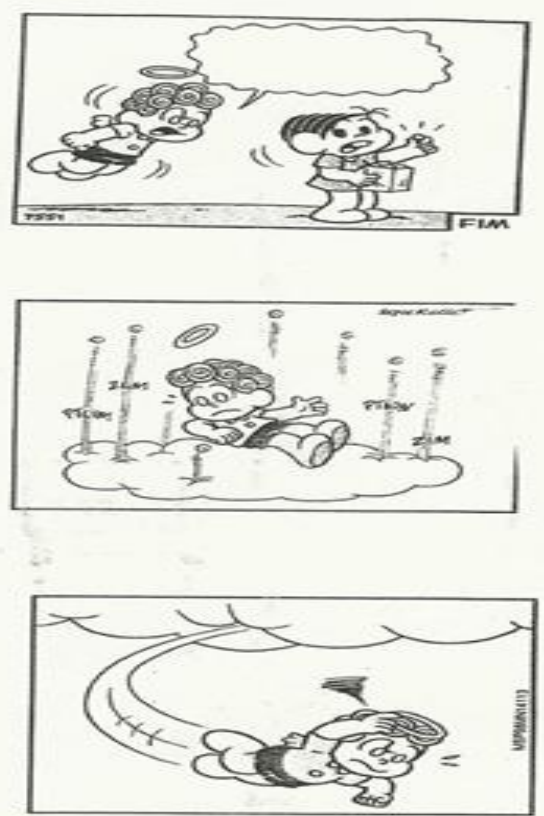
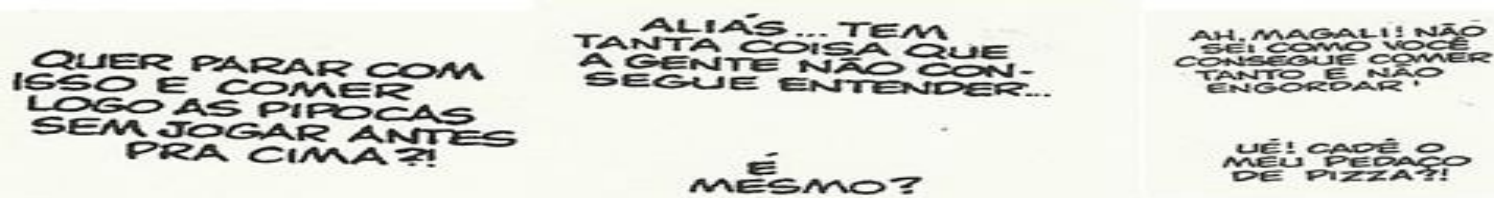

Fonte - elaborada pela autora.

Aplicada a uma turma de $2^{\circ}$ ano do Ensino Fundamental, essa atividade tinha como objetivo auxiliar o desenvolvimento das habilidades de leitura e compreensão dos alunos, que deveriam ler textos curtos e simples, sendo capazes de encontrar informações previsíveis e concretas em texto de uso corrente. Para isso, estão embaralhadas as falas dos personagens das duas tiras em quadrinhos, assim como as próprias cenas também estão fora de ordem. Lançando mão dos conhecimentos que construíram, eles deveriam organizar as tiras e completar com as frases na sequência correta. A atividade foi feita em duplas, para que pudessem discutir as hipóteses com seus pares. Foi um exercício interessante e os estudantes 


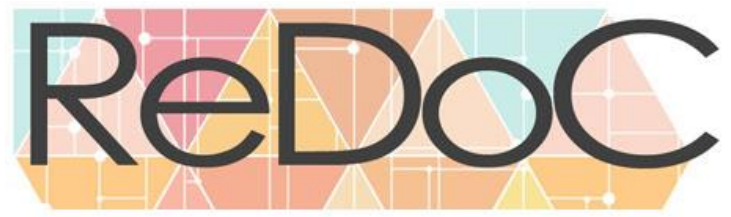

Revista Docência e Cibercultura

demonstraram bastante interesse, tendo apontado as imagens como um importante auxílio na compreensão leitora.

Gesuely e Moura (2006), no artigo intitulado 'Letramento e surdez: a visualização das palavras', discorrem sobre os potenciais educativos da utilização de recursos visuais como as HQ no processo de letramento dos surdos, lembrando-nos de que as imagens não são apenas um apoio momentâneo a ser superado no processo de aquisição da escrita, mas são constitutivas desse processo.

Consideramos esse um momento do processo de letramento em que a criança faz intenso uso da imagem na produção do texto, com indícios da aprendizagem da escrita do português que se apresenta pela produção de palavras que são do domínio da criança. A utilização de imagens e de um software que dispõe de diversos recursos visuais (personagens, cenários, etc.) insere-se no que estamos considerando como letramento visual. São imagens que se transformam em textos, ou seja, que não somente transmitem mensagens, mas que estão inseridas e significam as práticas sociais e discursivas desses alunos [...] O aspecto visual da leitura-escrita é um fator facilitador no processo de aquisição do português como segunda língua. No caso do ouvinte, o desenho é sempre visto como uma etapa a ser superada no decorrer do processo, no caso do surdo ele sempre estará presente. Não se trata de uma metodologia fundada na imagem, mas de tomar a imagem também como constitutiva do processo (p. 120).

Para Martins e Martins (2011) é fundamental que o educador esteja atento à visualidade do surdo, criando estratégias que mobilizem aprendizados críticos daquilo que é 'olhado'. No texto apresentado pelas autoras, são descritos resultados positivos na aprendizagem da língua escrita, pautados por aspectos visuais também, como as histórias em quadrinhos (Figura 4). 


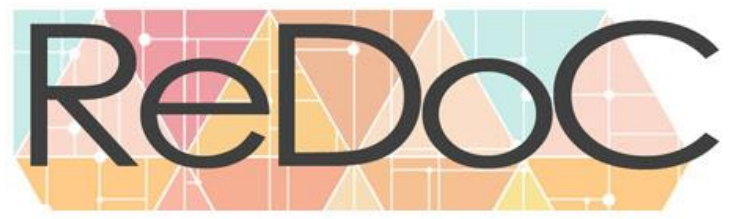

Revista Docência e Cibercultura

Figura 4 - Letramento visual: HQ

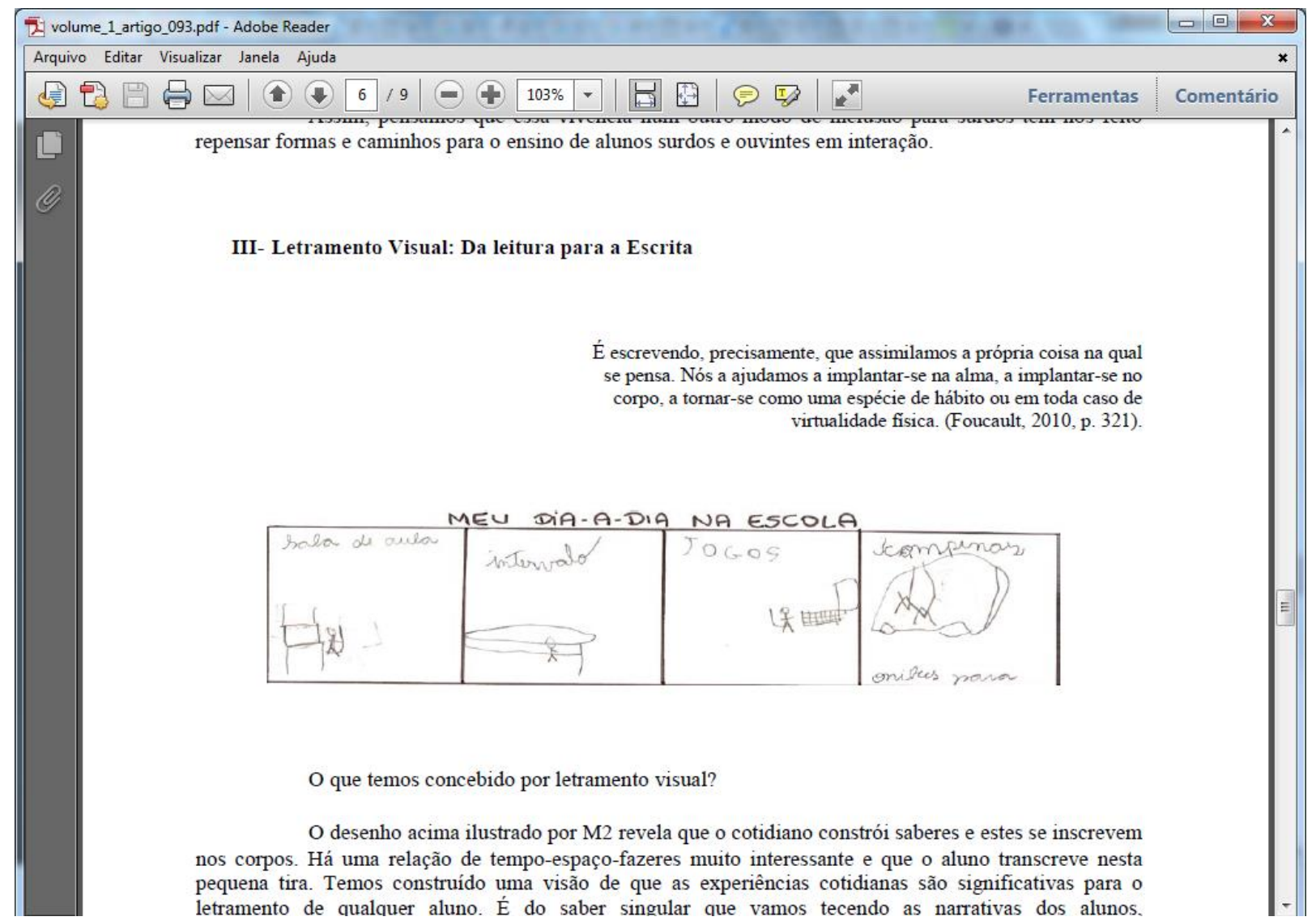

Fonte: Martins e Martins, 2011, p. 865.

Nas palavras das autoras:

O letramento visual é apontado por como sendo o modo de experimentar as práticas culturais/sociais por meio da visão. Ler os acontecimentos, fazer parte da dinâmica da vida aprendendo que há uma construção singular no corpo do surdo que o coloca em outra relação com as questões do cotidiano [...] o ensino da língua portuguesa, por exemplo, deve estar inserido neste modo de entendimento com propostas visuais que partam da realidade e necessidade comunicativa, o que implica numa reestruturação dos modos de ensinar e avaliar os alunos. Estamos afirmando que há de se construir um ensino visual que traga a noção de letramento visual. De uso, de práticas, portanto, um ensino baseado em propostas de segunda língua, mas que traz bem perto a LIBRAS ou primeira língua de aquisição. Por quê? Há que fazer presente no corpo surdo a vivencia daquilo que em palavras (numa outra língua) ele irá ler, registrar. Quando a LIBRAS faz parte deste cenário, há uma estrutura... um 
corpo que oferece materialidade para o surgimento de uma outra língua. (MARTINS; MARTINS, 2011, p. 865).

Com efeito, na linguagem verbal, a palavra possibilita formular generalizações e desenvolver o raciocínio classificatório. No entanto, em relação aos surdos, afirmam Nery e Batista (2004), a representação visual constitui elemento facilitador do processo de interação e tessitura do conhecimento, ao estabelecer relações e comparações, favorecendo o pensamento relacional.

Dos exemplos aqui apresentados, podemos perceber a predominância de recursos visuais centrados em ilustrações em LIBRAS - desenhos dos sinais, na tessitura do conhecimento dos surdos. Mas existem, certamente, muitas outras possibilidades. E aí, parece residir importante diferença entre o professor ouvinte que pensa a visualidade como adaptação didática, e o profissional surdo, que concebe a visualidade como prática fundamental, estruturante do pensamento.

Um material criado pelo Instituto Helena Antipoff - departamento responsável pelas práticas de inclusão escolar no município do Rio de Janeiro - traz alguns relatos das atividades visuais desenvolvidas por professores surdos na rede municipal de educação. $\mathrm{O}$ documento menciona uma pedagogia do jeito de ser surdo, afirmando que "Precisamos nos debruçar sobre os materiais criados pelos profissionais instrutores surdos das Escolas Municipais do Rio de Janeiro e referenciá-los em nossa prática pedagógica" (IHA, 2013). Essa afirmação parte da compreensão de que os professores surdos utilizam formas ricas de visualidade. $\mathrm{O}$ documento, sintetizado no Quadro 1, adiante, apresenta as práticas pedagógicas surdas como tendo as seguintes características:

Quadro 1 - Práticas pedagógicas surdas

\footnotetext{
Visualidade $\quad$ •Uso da visão; visão periférica.

Motor Cognitivo

-Acionar o motor cognitivo captando informações no seu canal de comunicação -
}

\begin{tabular}{l|l} 
v. 4 & n.1
\end{tabular}

p. 160 


\section{ReDoC}

\section{Revista Docência e Cibercultura}

\begin{tabular}{|c|c|}
\hline & que é visual. \\
\hline $\begin{array}{c}\text { Viso-gestual- } \\
\text { táteis }\end{array}$ & $\begin{array}{l}\text {-Modalidades viso-gestual-táteis (VGT), uso da visão e da presença física - olhar, } \\
\text { posição no espaço, expressão facial. } \\
\text { •Não é apenas a língua de sinais, mas outros aspectos do meio visual, como os } \\
\text { gestos; também fazer uso do corpo fisicamente, tanto para aprender quanto para } \\
\text { mostrar o que foi aprendido. }\end{array}$ \\
\hline $\begin{array}{c}\text { Cênica } \\
\text { Performance }\end{array}$ & $\begin{array}{l}\text { - Uso do espaço físico onde aluno surdo é levado à frente da sala de aula para se } \\
\text { posicionar, atuar, exercer influência. } \\
\text {-Performance: personagens ganham vida nas mãos do bom sinalizador; transporta } \\
\text { habilmente a cenários. } \\
\text { •Encorajamento dos alunos a fazerem demonstrações. }\end{array}$ \\
\hline Estó & $\begin{array}{l}\text {-Importância do humor contido em piadas, em relatos, teatralizações. } \\
\text {-Importância de contar estórias, fazer brincadeiras com a língua de sinais como parte } \\
\text { das pedagogias surdas }\end{array}$ \\
\hline Espaço Seguro & $\begin{array}{l}\text {-Acúmulo de informações para viver entre duas culturas; instruções culturais, morais. } \\
\text { •Coletivismo: Apoio moral e afetivo agregando-se o maior número de surdos em } \\
\text { escolas. } \\
\text { •Preservação de língua e cultura como herança de comunidade surda. }\end{array}$ \\
\hline $\begin{array}{c}\text { Espaço } \\
\text { alternativo }\end{array}$ & $\begin{array}{l}\text { - Sociabilidade em espaços de escola, de associações, em espaços comemorativos. } \\
\text {-Espaços alternativos de aprendizagem podem agregar: pátio da escola, auditório, } \\
\text { aulas-passeio, ambiente virtual, uso de redes sociais Internet. }\end{array}$ \\
\hline Diálogo & $\begin{array}{l}\text { - Importância na formulação de perguntas tanto do aluno para o adulto surdo quanto } \\
\text { deste para o grupo. } \\
\text { • Objetividade de discurso; discurso direto, claro, não-paternalista. } \\
\text { •Interação intensa por meio de relatos de experiência de vida. }\end{array}$ \\
\hline Holismo & $\begin{array}{l}\text {-Disciplina para a vida e grande esforço e empenho da pessoa surda. } \\
\text {-A vida representada como uma integração de todas as suas perspectivas, incluindo a } \\
\text { espiritual, a física, a ética e a emocional. }\end{array}$ \\
\hline
\end{tabular}

Fonte: IHA, Web, 2013. 
Como apresentado por Marques (1999) e Campello (2008), o processamento cognitivo do surdo é não somente facilitado, mas também fundamentado nos signos visuais. Não se trata apenas de um recurso complementar, mas uma mola propulsora para desencadear pensamentos.

Sacks (2010), neurologista inglês, professor e escritor de vários importantes livros, afirma em sua obra "Vendo Vozes: uma viagem ao mundo dos surdos", o caráter fundamental que a língua de sinais assume no processamento cognitivo dos indivíduos. Seu texto, originalmente escrito em 1989, traz em diversos trechos pistas sobre o funcionamento cognitivo-visual dos surdos, com vários apontamentos sobre as mudanças neurais que podem ocorrer nesse processo, inclusive sobre o potencial desenvolvimento de uma "visualidade superior" envolvendo as funções cognitivas dos surdos.

Podemos entender por que o usuário da língua de sinais torna-se uma espécie de "perito" visual de várias maneiras, em determinadas tarefas não linguísticas assim como nas linguísticas - por que ele pode desenvolver não apenas a linguagem visual, mas também uma especial sensibilidade e inteligência visual (p. 92).

Essa capacidade de 'inteligência' visual do surdo é descrita em outros momentos da obra, e encontra eco nas 'falas' aqui apresentadas, como por exemplo, no relato, trazido pelo autor, de um poeta e novelista sul-africano, surdo, chamado David Wright, que diz poder ouvir quando vê o que está ao seu redor, traduzindo movimentos em sons:

[Minha surdez] ficou mais difícil de perceber porque desde o princípio meus olhos inconscientemente haviam começado a traduzir o movimento em som. Minha mãe passava grande parte do dia ao meu lado e eu entendia tudo o que ela dizia. Por que não? Sem saber, eu vinha lendo seus lábios a vida inteira. Quando ela falava, eu parecia ouvir sua voz. Foi uma ilusão que persistiu mesmo depois de eu ficar sabendo que era uma ilusão. Meu pai, meu primo, todas as pessoas que eu conhecia conservaram vozes fantasmagóricas. Só me dei conta de que eram imaginárias, projeções do hábito e da memória, depois de sair do hospital. Um dia eu estava conversando com meu primo, e ele, num momento de inspiração, cobriu a boca com a mão enquanto falava. Silêncio! De uma vez por todas, compreendi que quando eu não podia ver eu não conseguia escutar (Idem, p. 18). 
Emmanuelle Laborit, atriz surda autora do livro "Grito da gaivota", publicado em 1994, registra de modo interessante sua vivência por meio das imagens: "Tenho minha imaginação, e ela tem seus barulhos em imagens. Imagino sons em cores. Meu silêncio tem, para mim, cores. Nunca é preto ou branco".

Campello (2008, p. 117) afirma que a experiência visual é dinâmica e um signo é como uma energia visual para o surdo. "Não há apenas uma combinação de signos, cores e formas, movimentos e tamanhos: a representação visual é assim como a melodia de uma música presente em interações dialógicas mediadas pela visualidade”. Nessa mesma perspectiva, Vilhalva (2004), nos ensina um pouco sobre a importância que a imagem assume no universo do surdo:

Todas informações que eu recebia dependiam de meus olhos, eu olhava e depois ficava observando o que acontecia e o que poderia acontecer, sem muita preocupação com as outras crianças ou adultos que estavam à minha volta. Crescendo por dentro e por fora, fui entendendo melhor o mundo e essa formação de mundo era feita visualmente, como se a caixinha que tinha dentro de minha cabeça estava ficando cheia, pois tudo que olhava era como se eu tirasse uma fotografia e ia guardando, assim ficava por muito tempo guardada as imagens paradas. (p.14)

Assumir sua própria identidade, ou seja, aquilo que constitui o sujeito, em sua essência, sem ignorar fraquezas, deficiências, marcas e ausências, constitui uma das tendências contemporâneas, em que tudo pode ser considerado fonte de criação e de inspiração, passível de aproveitamento. Nessa perspectiva, cresce em relevância o princípio de alteridade, na medida em que é preciso reconhecer a existência das diferenças físicas e culturais, garantindo assim o direito de todos se expressarem nas suas múltiplas formas, no pleno exercício da cidadania. 


\section{Rastros culturais imagéticos indicadores de aprendizagem na cibercultura}

Vivemos a "modernidade líquida" (Bauman, 2006), tempos marcados pela incerteza, pela volatilidade e pela flexibilidade A cibercultura, cultura contemporânea, mediada pelo digital em rede, modifica modos de produção, de sociabilidade, de aprendizagem e de educação (SANTOS, 2019), ampliando as possibilidades de docência.

Para Alves (2012) nos cotidianos, as pessoas se articulam em múltiplas redes educativas, que formam e nas quais se formam. Os inúmeros encontros proporcionados nas redes sociais da Internet, com professores, orientadores, colegas de turma, e tantos outros interlocutores, contribuem, significativamente, para nossa formação como “docentespesquisadores", possibilitando a emersão de processos reflexivos com vistas ao aprimoramento das ideias e da própria pesquisa. $\mathrm{Na}$ ótica da autora,

[...] a incorporação dessas redes do que se aprende fora da escola e que é trazido para escola como experiências vividas externamente, que passam a ser vividas internamente, é que movimenta o ensino, renova o ensino. Porque o ensino não é renovado por decreto, ele é efetivamente renovado no concreto dele, no cotidiano dele, na compreensão daquele conjunto de professores de uma determinada escola, com o acesso que eles começam a ter às múltiplas redes educativas e, dessa forma, começam a fazer transformações. (...). Então são essas tais redes das quais nós participamos e que não estão fora da escola, elas estão dentro da escola, porque vão dentro das pessoas que vão à escola fazer a escola (p. 3).

Conhecer e compreender esses princípios pode ser um importante diferencial em nossa prática educativa. No contexto da cibercultura, entendemos haver práticas de visualidades muito potentes, que podem contribuir ainda mais fortemente com o repertório formativo dos surdos (e dos ouvintes).

Nesse contexto, apresentamos um vídeo compartilhado recentemente em um grupo no Facebook que nos chamou a atenção (Figura 7). Nele, um rapaz aparece fazendo a sinalização em LIBRAS de uma animação da Disney chamada "O carnaval dos animais", em que

\footnotetext{
${ }^{5}$ Vídeo original, disponível em: https://www.youtube.com/watch?v=Gvk8_o7VxyY . Acesso em: 12 abr. 2020.
}

\begin{tabular}{l|l|} 
v. 4 & n.1
\end{tabular}


aparecem flamingos dançando e brincando ao som da música de Camille Saint-Saëns. A perfeição das expressões corporais e faciais do rapaz nos permite vislumbrar, por meio de suas mãos, toda a riqueza da cena do vídeo original. Para nós, ouvintes, o som da música complementa a cena. Mas para o surdo, é preciso ir além. Ele transformou em língua visual, toda informação presente no desenho animado; o que evidencia uma riqueza cultural considerável (Figura 5).

Figura 5 - Imagens em movimento expressas em LIBRAS
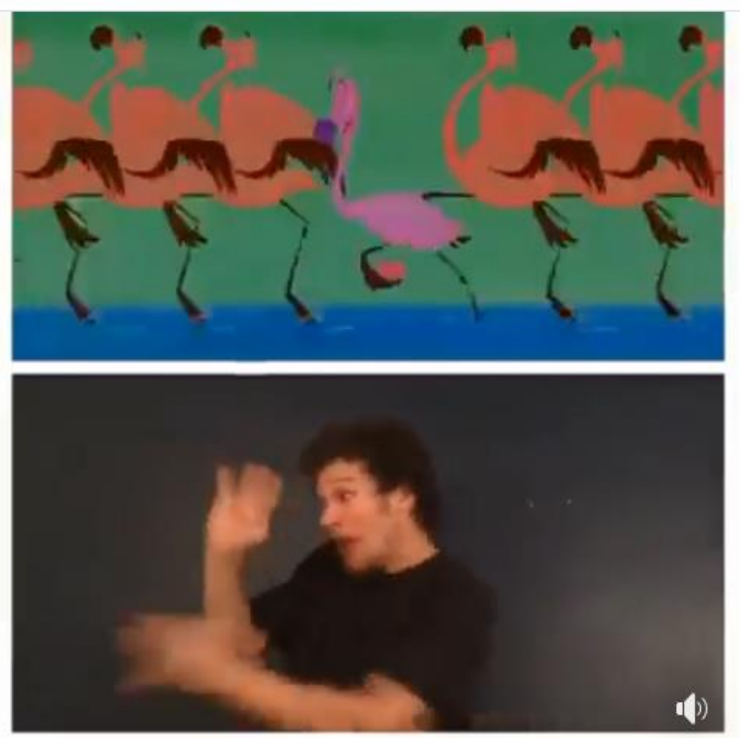

군 Curtir

$\Leftrightarrow$ Compartilhar

Fonte - Disponível em: https://www.facebook.com/groups/redutra.linguadesinais/ permalink /1092607050882456/ . Acesso em: 12 abr.2020.

Essa riqueza de expressividade é vista nas diversas produções denominadas Visual Vernacular (ou VV) que são um estilo de expressão artística desenvolvido e representado por pessoas surdas, baseados na percepção dos classificadores das línguas de sinais e suas características de forma, tamanho e ações (ABRAHÃO, 2017, p. 5079). A Internet está repleta de produções Visual Vernacular, não só de surdos utilizando a Língua Brasileira de Sinais, mas em diferentes línguas dos mais diversos países. 


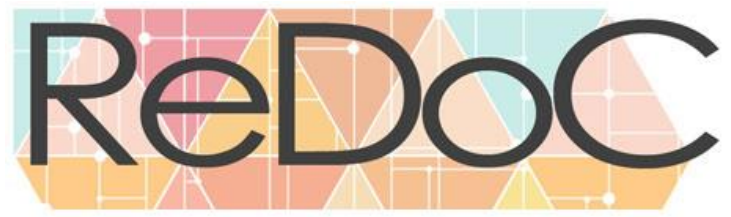

\section{Revista Docência e Cibercultura}

Para o autor, o Visual Vernacular é um meio eficaz para ensino dos surdos, estabelecendo uma proposição reflexiva que "deixa de ser uma mera tradução e interpretação de textos oriundos da cultura ouvinte, ao se apresentar como uma produção estética com características específicas" (p. 5080). Além disso, o Visual Vernacular constitui uma experiência importante para que as pessoas ouvintes tenham vivências e conhecimentos sobre a comunidade surda

Portanto, na expressão literária surda, corpo, língua, movimento e comunicação conjugam-se. Essa conjugação, como dito, será desenvolvida através de estratégias de performance, nas quais formam-se e conformam-se objetos artísticos de uma presença lábil e irrepetível, exceto quando registradas por tecnologias de reprodução da imagem. Criam-se modos de performar o literário em jogos que hibridizam traços dramáticos, narrativos e líricos, bem como outros provenientes das linguagens artísticas da dança, das Artes Plásticas e do cinema (RAMOS; ABRAHÃO, 2018, p.62).

Figura 6 - Visual Vernacular no Instagram
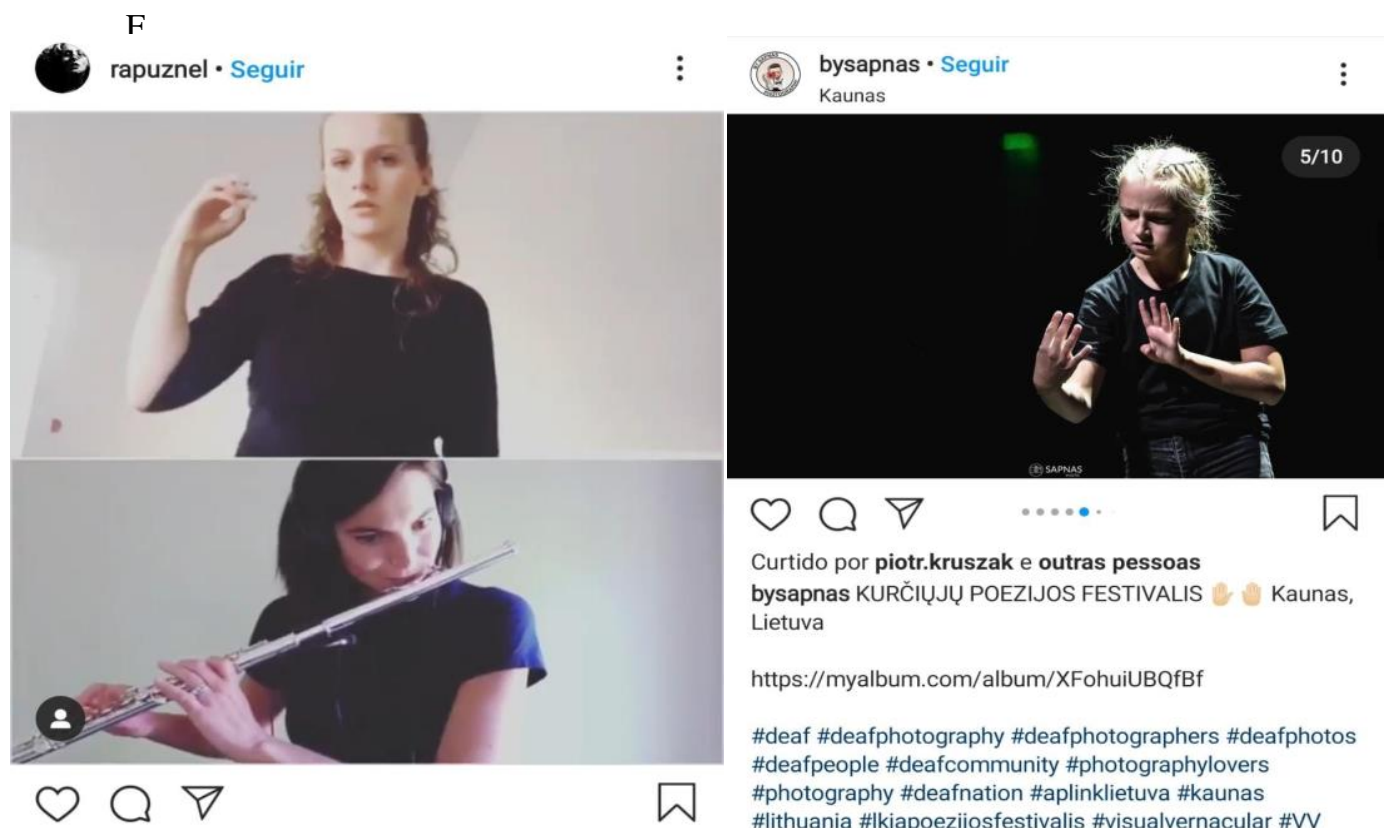

Curtido por piotr.kruszak e outras pessoas bysapnas KURČIỤJỤ POEZIJOS FESTIVALIS 0 Kaunas, Lietuva

https://myalbum.com/album/XFohuiUBQfBf

\#deaf \#deafphotography \#deafphotographers \#deafphotos \#deafpeople \#deafcommunity \#photographylovers \#photography \#deafnation \#aplinklietuva \#kaunas \#lithuania \#lkjapoezijosfestivalis \#visualvernacular \#VV

Curtido por p_kkaln e outras pessoas 30 de setembro de 2019 · Ver tradução

rapuznel Rocking Horse: Collaboration with @ruthflute and @_melissakeeling... mais

$\underline{\mathrm{n}}$

Fonte:https://www.instagram.com/p/Bzc6vg9ngsF/?igshid=zkhkj9id7cyj https://www.instagram.com/p/B3BfCzWopWb/?igshid=gegky5hs190n . Acesso em: 12 abr.2020. 
A comunicação constitui o meio que nos possibilita elaborar, trocar, transmitir, expressar, traduzir, mobilizar afetos, ideias, opiniões, crenças, necessárias à persecução dos objetivos. No entanto, as relações educativas são atravessadas por referências outras, tecidas em diferentes dimensões, como: psicológicas, sociais, econômicas, políticas, e sociais, que, não raras vezes se expressam de forma incompreensível, e resistentes a qualquer tipo de interpretação. Isso exige considerar que a realidade é plural, multirreferencial, assumindo a intersubjetividade, para que, a partir das diferenças, um novo conhecimento possa ser tecido, na práxis social.

Exercitar a aprendizagem sociocultural; ou seja, compreender a cultura exige que o pesquisador "reaprenda, reavalie, desconstrua, reconstrua os seus próprios valores do que é ser um sujeito social e suas realizações”, como nos ensina Macedo, (2016, p. 76).

Como podemos constatar, além da racionalidade, a tessitura do conhecimento envolve vários fatores, tais como motivação, interatividade, mediação, abertura para o novo, negociação de sentidos, entre outros, possibilitando o desvelamento do objeto e do sujeito. Ao mesmo tempo em que o processo "aprendizagemensino" evoluía, a formação docente e discente ia se constituindo na relação de alteridade.

Estamos aqui enfatizando todos esses relatos por entender a importância da visualidade para a pessoa surda que percebe, apreende e significa o mundo por meio de experiências visuais.

A própria definição de surdo, apresentada pela legislação sobre língua de sinais no Brasil, destaca o caráter visual do ser surdo:

Art. $2^{\mathbf{o}}$ - Para os fins deste Decreto, considera-se pessoa surda aquela que, por ter perda auditiva, compreende e interage com o mundo por meio de experiências visuais, manifestando sua cultura principalmente pelo uso da Língua Brasileira de Sinais - LIBRAS (BRASIL, 2005).

Com efeito, destacamos três aspectos que fundamentam o modo visual de vida dos sujeitos surdos: a compensação visual decorrente da falta sensorial da audição; a utilização da língua de sinais, que dada a sua natureza visual-espacial desencadeia esquemas de pensamento visual, bem como fortalece a identidade e cultura surdas, essencialmente visuais; e atrelado ao 
ponto anterior, os esquemas de pensamento visual, base não só das subjetividades, mas principalmente do processamento cognitivo, a inteligência visual.

Acreditamos, portanto, ser de vital importância destacar a questão aqui abordada, por ser ela - ou, ao menos, deveria ser - o viés norteador das práticas educativas centradas na visualidade para os sujeitos surdos.

Mas, se assim o é, por que, até hoje, tantos surdos ainda encontram uma enorme dificuldade no processo de escolarização? Por que ainda prevalecem práticas didáticas antagônicas aos preceitos anteriormente explicitados?

Para Skliar (1997), o fracasso na educação de surdos passa por cinco fatores principais: baixas expectativas pedagógicas dos educadores de surdos, que acabam sendo incorporadas pelos próprios surdos; as várias formas de colonização do currículo, na medida em que, nos projetos e programas de cursos, não se contemplam as especificidades linguístico-culturais da comunidade surda; a supremacia do clínico sobre o pedagógico; o desconhecimento (ou não reconhecimento) das estratégias de ensinar e aprender dos surdos; a não participação dos surdos e suas comunidades nas discussões e decisões pedagógicas nas diferentes instâncias de poder (governamental e institucional).

Campello (2008) afirma que o fracasso na educação dos surdos também se deve ao fato de ainda predominarem práticas centradas numa visão fonocêntrica.

\footnotetext{
A educação e sua pedagogia não compreendeu ou desconheceu os métodos próprios para o ensino de sujeitos Surdos, isso se deve ao fato de o espaço educacional estar permeado de ações de controle e poder e de visão fonocêntrica que supervalorização da língua oral e da cultura não-surda (Op. cit., p. 49).
}

A autora aponta alguns motivos que, para ela, dificultariam a efetivação da educação de surdos, como: a) despreparo dos professores quanto a Língua de Sinais, que acabam utilizando métodos mistos de comunicação, não possibilitando efetivamente a prática bilíngue; b) formação dos professores que ignora as questões relacionadas à importância da visualidade para os sujeitos surdos; c) a predominância de paradigmas ouvintistas e concepção clínica da surdez como deficiência; d) desconhecimento (ou desvalorização) da 
cultura e identidade surda; e) biologização da surdez e a desconsideração de questões próprias do sujeito surdo e da surdez.

Sobre a questão da colonização do currículo e a supremacia do olhar clínico, Machado (2009), nos lembra de que não basta apenas incluir a língua de sinais nos espaços da vida cotidiana; é preciso romper com olhares dominantes ouvintistas:

\begin{abstract}
A descolonização ou desouvintização do currículo para surdos não será alcançada com medidas aparentes, como a inclusão da língua de sinais na escola ou a contratação de surdos como meros auxiliares da "transmissão" de conteúdos e textos selecionados pela ótica dominante, que continua subestimando o sujeito surdo e sua educação. Os projetos de educação bilíngüe só produzirão o descentramento no projeto educativo da questão das línguas se atuarem sobre a necessária transformação das representações dominantes na educação de surdos (p. 69).
\end{abstract}

Refletindo sobre as questões trazidas, entendemos ser de grande valia a temática aqui levantada, na qual procuramos apresentar alguns potenciais educativos na perspectiva das visualidades na rede mundial de computadores. E em meio a tantas produções acerca da educação de surdos, queremos fazer coro àquelas que acreditam na importância da educação bilíngue, pautada numa perspectiva da visualidade surda. Nesse sentido, enfatizamos que a educação de surdos não basta ser bilíngue, é preciso ser visual. Visual para além da ilustração estética valorizando outras formas de "aprenderensinar" que ultrapassem a tradicional transmissão de conteúdos centrada na oralidade e, consequentemente, centrada na figura do professor.

\title{
CONSIDERAÇÕES FINAIS
}

Acreditamos que a educação de surdos nos convida a um (re)aprendizado do olhar, a um olhar sensível. Uma aprendizagem visual e de leitura de imagens que não acontece de forma mágica ou milagrosa, mas que é construção processual, tecida nas redes dos muitos aprendizados nos "espaçostempos" da vida cotidiana.

O professor, a partir do olhar sensível que forma e se forma, nas inúmeras experiências visuais cotidianas, pode contribuir com propostas mais adequadas ao ensino de surdos, tendo 


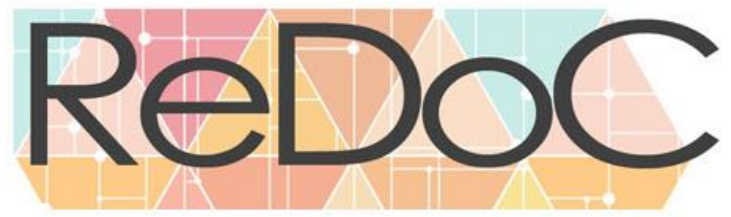

Revista Docência e Cibercultura

como base a visualidade. Essas experiências podem contribuir na criação de lugares de acolhimento das individualidades e subjetividades de cada um. Exercitamos o olhar e o fazer, integrando pensamento e sentimento, sensação e intuição, afirmando a arte como espaço da totalidade, e o espaço do ensino da arte como lugar de muitos segredos. Esse olhar que aprende, que lê, que interpreta, que questiona e que sente, é construído, permanentemente. É em busca desse olhar que estamos. Buscando pistas de como o olhar do pesquisador, do professor, pode ajudar a oportunizar a formação de tantos outros olhares.

\section{REFERÊNCIAS BIBLIOGRÁFICAS}

ABRAHÃO, B. Literatura surda em performance: considerações sobre a arte visual vernacular. Literatura surda em performance: considerações sobre a arte visual vernacular. 2017. (Apresentação de Trabalho/Comunicação). Disponível em: http://www.abralic.org.br/anais/arquivos/2017_1522245161.pdf Acesso em: 13 abr. 2020.

ALVES, N. Políticas e cotidianos em redes educativas e em escolas. XVI Encontro Nacional de Didática e Práticas de Ensino - ENDIPE/UNICAMP - Campinas, 2012.

AMARAL, L. Sobre crocodilos e avestruzes. São Paulo: Summus, 1998.

ANDRADE, N.; CALDAS, A.; ALVES, N. Os movimentos necessários às pesquisas com os cotidianos - 'após muitas conversas acerca deles'. In: Oliveira, I.; Peixoto, L.; Süssekind, M. L. (Orgs). Estudos do cotidiano, currículo e formação docente: questões metodológicas, políticas e epistemológicas. Curitiba: CRV, 2019, p. 1945.

ARDOINO, J. L'approche multiréférentielle (plurielle) des situations éducatives et formatives. Pratiques de Formation-Analyses. Saint-Denis, 1998.

BRASIL. Lei $n^{\circ} 7853$, de 24 de outubro de 1989. Dispõe sobre o apoio às pessoas portadoras de deficiência, sua integração social, sobre a Coordenadoria Nacional para Integração da Pessoa Portadora de Deficiência - Corde, institui a tutela jurisdicional de interesses coletivos ou difusos dessas pessoas, disciplina a atuação do Ministério Público, define crimes, e dá outras providências. Brasília, DF, 1989. Disponível em: http://www.planalto.gov.br/ ccivil_03/leis/17853.htm. Acesso em: 13 abr. 2020.

BRASIL. Lei $n^{o}$ 8.213, DE 24 de julho de 1991. Dispõe sobre os Planos de Benefícios da Previdência Social e dá outras providências. Brasília, DF, 1989. Disponível em: http://www.planalto.gov.br/ccivil_03/leis/18213cons.htm. Acesso em: 14 abr. 2020. 


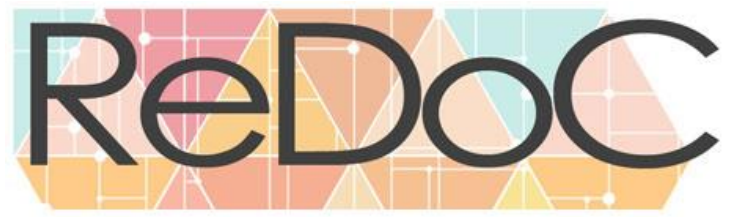

Revista Docência e Cibercultura

BRASIL. Lei $n^{o}$ 10.436, de 24 de abril de 2002. Dispõe sobre a língua brasileira de sinais. Brasília, DF, 2002. Disponível em: http://www.planalto.gov. br/ccivil_03/leis/ 2002 /110436 .htm. Acesso em: 13 abr. 2020.

BRASIL. Decreto $n^{\circ}$ 5.626, de 22 de dezembro de 2005. Regulamenta a Lei $n^{\circ} 10.436$, de 24 de abril de 2002, que dispõe sobre a Língua Brasileira de Sinais - LIBRAS, e o art. 18 da Lei ${ }^{\circ} 10.098$, de 19 de dezembro de 2000. Brasília, DF, 2005. Disponível em: http://www2.camara.leg.br/legin/fed/decret/2005/decreto-5626-22-dezembro-2005-539842publicacaooriginal-39399-pe.html. Acesso em: 13 abr. 2020.

BAUMAN, Z. Modernidade líquida. Rio de Janeiro: Jorge Zahar, 2006.

CAMPELlO, A. R.. Aspectos da visualidade na educação de surdos. Tese (Doutorado) - Curso de Educação, Universidade Federal de Santa Catarina, Florianópolis, 2008. Disponível em: http://repositorio.ufsc.br/xmlui/handle/123456789/91182. Acesso em: 13 abr. 2020.

CERTEAU, M. de. A invenção do cotidiano: artes de fazer. $20^{a}$ ed. Petrópolis: Vozes, 2013.

GESUELI, Z. M.; MOURA, L. Letramento e surdez: a visualização das palavras. Etd - Educação Temática Digital, 13 nov. 2008, [s.1.], v. 7, nº 2, p.110-122. Universidade Estadual de Campinas. DOI: http://dx.doi.org/10.20396/etd.v7i2.796. Disponível em: https://periodicos.sbu.unicamp.br/ojs/index.php/etd/article/view/796. Acesso em: 13 abr. 2020.

IHA - Laboratório de LIBRAS. Cultura e pedagogia surda: recursos visuais na prática pedagógica. IHA - Laboratório de LIBRAS. Prefeitura do Rio de Janeiro. Publicado em 2013. Disponível em: http://jottaclub.com/wp-ontent/uploads/2015/06/ recursosvisuais na prticapedaggicaculturaepedagogiasurda-130225160121-phpapp02.pdf. Acesso em: 13 abr. 2020.

JORGE, E. E. Sentidos das práticas avaliativas na sala de aula de espanhol como língua adicional no cotidiano escolar do aluno surdo. Pensares em Revista. Universidade de Estado do Rio de Janeiro, 2013, [s.1.], no. 2, p. 109-135, DOI: http://dx.doi.org/10.12957/pr.2013.7606. Disponível em: http://www.e-publicacoes. uerj.br/index.php/pensaresemrevista/article/view/7606. Acesso em: 13 abr. 2020.

LACERDA, C. A inclusão escolar de alunos surdos: o que dizem alunos, professores e intérpretes sobre esta experiência de inclusão escolar de alunos surdos: o que dizem alunos, professores e intérpretes sobre esta experiência. Caderno Cedes. Campinas, mai.-ago. 2006, v. 26, no 69, p. 163-84. Disponível em: http://www.scielo.br/pdf/\%0D/ccedes/v26n69/a04v2669.pdf. Acesso em: 13 abr. 2020.

MACEDO, R.. A pesquisa e o acontecimento: compreender situações, experiências e saberes acontecimentais. Salvador: EDUFBA, 2016. 
MACHADO, P. C. Diferença cultural e educação bilíngüe: as narrativas dos professores surdos sobre questões curriculares. 2009. 164 f. Tese (Doutorado) - Curso de Educação, Universidade Federal de Santa Catarina, Florianópolis, 2009. Disponível em: https://repositorio.ufsc.br/bitstream/handle/123456789/92494/266573.pdf?sequence=1.Acesso em: 13 abr. 2020.

MARQUES, C. V. Visualidade e surdez: a revelação do pensamento plástico. Revista Espaço. Instituto Nacional De Educação De Surdos, Rio de Janeiro, 1999, p. 38-47.

MARTINS, V. R; MARTINS, L. Experiências de letramento visual na constituição da LIBRAS e do português por alunos surdos numa escola regular. I SIMPÓSIO INTERNACIONAL DE ENSINO DE LÍNGUA PORTUGUESA. Uberlândia. Anais. Uberlândia: Edufu, 2011. v. 1, p. 859 - 867. Disponível em: $\quad$ http://www.ileel.ufu.br/anaisdosielp/wp-content/uploads/ 2014/06/ volume_1_artigo_093.pdf. Acesso em: 13 abr. 2020.

NERY, C.; BATISTA, C. Imagens visuais como recursos pedagógicos na educação de uma adolescente surda: um estudo de caso. Paidéia. Ribeirão Preto, dez. 2004, [s.1.], v. 14, nº 29, p. $287-$ 299. FapUNIFESP (SciELO). DOI: http://dx.doi.org/10.1590/s0103-863x2004000300005. Disponível em: http://www.scielo. br/scielo. php? pid=S0103- 863X2004000300005\&script=sci_abstract\&tlng =pt. Acesso em: 13 abr. 2020.

PERLIN, G. Surdos: cultura e pedagogia. 2006. Disponível em: https://pt.scribd.com/ document/88378969/Surdos-Cultura-e-Pedagogia-Gladis-Perlin. Acesso em: 13 abr. 2020.

PERLIN, G.; STRÖBEL, K. Fundamentos da educação de surdos. Florianópolis: UFSC, 2008. Disponível em: http://www.LIBRAS.ufsc.br/colecaoLetrasLIBRAS/eixo Formacao Especifica/fundamentosDaEducacaoDeSurdos/assets/279/TEXTO_BASE-fundamentos $\quad$ Educ _Surdos.pdf. Acesso em: 13 abr. 2020.

RAMOS, D.; ABRAHAO, B. Literatura surda e contemporaneidade: contribuições para o estudo da Visual Vernacular. Pensares em Revista, 2018, v. 12, p. 56-72. Disponível em: https://www.epublicacoes.uerj.br/index.php/pensaresemrevista/article/view/34059. Acesso em: 13 abr. 2020.

SACKS, O. Vendo vozes: uma viagem ao mundo dos surdos. São Paulo: Companhia das Letras, 2010.

SANTOS, S. Educação ambiental: recursos imagéticos na produção de significação de um sujeito surdo. Dissertação (Mestrado em Educação Ambiental). Universidade Federal Rio Grande, 2013. Disponível em: http://repositorio.furg.br/handle/1/6002. Acesso em: 13 abr. 2020.

SANTOS, B; NUNES, J. Introdução: para ampliar o cânone do reconhecimento, da diferença e da igualdade. In: Santos, B. (Org.), Reconhecer para libertar: os caminhos do cosmopolitismo multicultural. Rio de Janeiro, Civilização Brasileira, 2003, p. 25-68.

SANTOS, E. Pesquisa-formação na cibercultura. Teresina: EDUFPI, 2019. 
SILVA, E.; KANASHIRO, E. Avaliação visual da aprendizagem: uma alternativa para alunos surdos. Estudos em Avaliação Educacional, 2015, [s.1.], v. 26, no 63, p. 688-714. Fundação Carlos Chagas. DOI: http://dx.doi.org/10.18222/eae.v0ix.3111. Disponível em: http://publicacoes.fcc.org.br/ojs/index.php/eae/article/view/3111/3115. Acesso em: 13 abr. 2020.

SKLIAR, C. Uma perspectiva sócio-histórica sobre a psicologia e a educação dos surdos. In: Skliar, C. (Org.). Educação e exclusão: abordagens socioantropológicas em educação especial. Porto Alegre: Mediação, 1997, p. 105-153. (Cadernos de autoria, 2).

STREIECHEN, E.; KRAUSE-LEMKE, C.; OLIVEIRA, J.; CRUZ, G. Pedagogia surda e bilinguismo: pontos e contrapontos na perspectiva de uma educação inclusiva. Acta Scientiarum. Education, 2016, [s.1.], v. 39, $\mathrm{n}^{\circ}$ 1, p. 91-101. Universidade Estadual de Maringa. DOI: http://dx.doi.org/10.4025/actascieduc.v39i1.26066. Disponível em: http://eduem.uem.br/ojs/index.php/ActaSciEduc/article/view/26066. Acesso em: 13 abr. 2020.

STRÖBEL, K. Surdos: vestígios culturais não registrados na história. Tese (Doutorado em Educação). Universidade Federal de Santa Catarina (UFSC), 2008. Disponível em: file:///C:/Users/Miriam/Downloads/Surdos\%20vest\%C3\%ADgios...\%20(Strobel).pdf. Acesso em: 13 abr. 2018.

STRÖBEL, K. As imagens do outro sobre a cultura surda. $2^{\text {a }}$ ed. rev. Florianópolis: UFSC, 2009.

VILHALVA, S. Despertar do silêncio. Petrópolis: Arara Azul, 2004. (Coleção Cultura e Diversidade). 